\title{
Effect of Moringa oleifera on advanced glycation end-product formation and lipid metabolism gene expression in HepG2 cells
}

\author{
W. Sangkitikomol ${ }^{1}$, A. Rocejanasaroj ${ }^{2}$ and T. Tencomnao ${ }^{1}$ \\ ${ }^{1}$ Center for Excellence in Omics-Nano Medical Technology Development Project, \\ Department of Clinical Chemistry, Faculty of Allied Health Sciences, \\ Chulalongkorn University, Bangkok, Thailand \\ ${ }^{2}$ Graduate Program in Clinical Biochemistry and Molecular Medicine, \\ Department of Clinical Chemistry, Faculty of Allied Health Sciences, \\ Chulalongkorn University, Bangkok, Thailand
}

Corresponding author: W. Sangkitikomol

E-mail: warin.s@chula.ac.th

Genet. Mol. Res. 13 (1): 723-735 (2014)

Received February 13, 2013

Accepted July 17, 2013

Published January 29, 2014

DOI http://dx.doi.org/10.4238/2014.January.29.3

\begin{abstract}
In Thai traditional medicine, Moringa oleifera is used for the treatment of diabetes and hyperlipidemia. Oxidative stress plays a major role in the pathogenesis of many degenerative diseases, such as hyperlipidemia, diabetes mellitus, and cardiovascular disease. We evaluated the antioxidant effect of $M$. oleifera extract (MOE) for reduction of advanced glycation end-product (AGE) formation, cell viability, oxidative stress, and lipid metabolism gene expression in HepG2 cells. We found that the lyophilized form of MOE in $80 \%$ ethanol possessed mean $( \pm \mathrm{SD})$ total antioxidant, polyphenolic, and flavonoid contents of $9307 \pm 364 \mathrm{TE} \mathrm{mM} / \mathrm{kg}$ dry mass, $218 \pm 1 \mathrm{GE} \mathrm{mM} / \mathrm{kg}$ dry mass, and $286 \pm 12 \mathrm{QE} \mathrm{mM/kg} \mathrm{dry} \mathrm{mass,} \mathrm{determined} \mathrm{using} \mathrm{an} \mathrm{oxygen}$ radical absorbance capacity assay, a Folin Ciocalteu phenol assay, and a total flavonoids assay, respectively. Concentrations of $2.5-10.0 \mathrm{mg} /$ $\mathrm{mL}$ MOE could inhibit AGE-formation by $10-45 \%$, and $100-1000 \mathrm{mg} / \mathrm{L}$
\end{abstract}


MOE reduced intracellular oxidative stress $(\mathrm{P}<0.05)$ in a dose-dependent manner in the DCFH-DA assay. However, MOE induced cytotoxicity at high doses (2000-3000 mg/L), as shown by the MTT assay. MOE significantly downregulated the mRNA expression of the HMG-CoAR, PPAR $\alpha 1$, and PPAR $\gamma$ genes $(\mathrm{P}<0.05)$. We concluded that M. oleifera could have benefits for human health by reducing oxidative stress and AGE formation. Moreover, M. oleifera may reduce cholesterol and lipid synthesis by suppression of HMG-CoAR, PPAR $\alpha 1$, and PPAR $\gamma$ gene expression, thereby maintaining lipid homeostasis.

Key words: Moringa oleifera; Antioxidant; AGE formation; HMG-CoAR; PPAR $\alpha 1$; PPAR $\gamma$

\section{INTRODUCTION}

Moringa oleifera is an important tropical crop that is used as a vegetable and in herbal medicine. All parts of $M$. oleifera can be used in Thai traditional medicine to treat human diseases (Chumark et al., 2008). Oxidative stress plays a major role in the pathogenesis of many degenerative diseases induced by free radicals, such as hyperlipidemia, diabetes mellitus, and cardiovascular disease. $M$. oleifera leaves appear to prevent oxidative damage by increasing the levels of liver antioxidant enzymes such as superoxide dismutase, catalase, glutathione peroxidase, glutathione transferase, and glutathione reductase; increases the levels of glutathione (GSH); and significantly reduces lipid peroxidation and antihepatotoxicity (Verma et al., 2009; Uma et al., 2010; Moyo et al., 2012). This plant possesses antioxidant, hypoglycemic, hypolipidemic, and antiatherosclerotic activities, which may prevent cardiovascular diseases in rabbits (Chumark et al., 2008).

Advanced glycation end-product (AGE) formation in the body involves non-enzymatic reactions between high blood glucose and free amino groups in proteins, lipids, and nucleic acids through a series of reactions forming Schiff bases and Amadori products (Sato et al., 2006; Takeuchi et al., 2010). AGE are products of both lipid peroxidation and glycoxidation reactions (Fu et al., 1996). Dietary advanced glycation end products (dAGEs) are commonly found in heat-processed animal-derived foods. Excess dAGEs in food are known to increase oxidative stress and inflammation, which are linked to chronic diseases. The pathological effect of dAGEs is similar to that of AGE formation in diabetic patients (Uribarri et al., 2005). Increased AGE content has been implicated in several chronic diseases, including diabetesrelated complications such as renal diseases, retinopathy, neuropathy, cardiovascular diseases, and delayed wound healing (Luevano-Contreras et al., 2013). M. oleifera might have an inhibitory effect on AGE formation, which could prevent diabetic complications.

The regulation of lipid homeostasis is related to the activity of 3-hydroxy-3-methylglutaryl-CoA reductase (HMG-CoAR), the rate-controlling enzyme of cholesterol synthesis inside the cells. A membrane receptor, low-density lipoprotein receptor (LDLR), is controlled by cholesterol levels inside the cell, and acts to remove LDL-cholesterol from the blood circulation, which contributes to decreased plasma cholesterol levels (Powell and Kroon, 1994). The nuclear membrane receptors, such as peroxisome proliferator-activated receptors [PPAR $(\alpha 1, \gamma)]$ and the liver $\mathrm{X}$ receptor $\alpha(\mathrm{LXR} \alpha)$ are important regulators of cholesterol, fatty acid, 
and adipocyte differentiation. Many studies have shown that the PPARs and LXR $\alpha$ pathways regulate lipid homeostasis and metabolic syndrome via both induction and suppression of target genes. These nuclear receptors are transcriptional factors that modulate the expression of genes relevant to the control of blood lipid and glucose homeostasis (Willson et al., 2001; Bays and Stein, 2003; Kaul et al., 2005; Calkin and Tontonoz, 2010). Although M. oleifera is known to reduce hyperlipidemia, the precise mechanism underlying this remains unclear. The aim of this study was to determine the effect of M. oleifera on the reduction of oxidative effects by using an antioxidant assay and an inhibition of AGE formation assay. Cell viability was investigated with the 3-(4,5-dimethylthiazol-2-yl)-2,5-diphenyl tetrazolium bromide (MTT) assay. Oxidative stress was determined using the dichloro-dihydro-fluorescein diacetate (DCFH-DA) assay, and the ability of $M$. oleifera to modulate the expression of lipid metabolism genes such as HMG-CoAR, LDLR, PPAR $(\alpha 1, \gamma)$, and LXR $\alpha$ was determined in HepG2 cells using reverse transcription-polymerase chain reaction (RT-PCR).

\section{MATERIAL AND METHODS}

\section{Chemicals}

Folin Ciocalteu phenol (FCP) reagent, MTT, ethidium bromide, 2',7'-DCFH-DA, Trolox, quercetin, gallic acid, and amino guanidine were purchased from Sigma-Aldrich (St. Louis, MO, USA). Dulbecco's modified Eagle's medium (DMEM), with $4 \mathrm{mM}$ glutamine and 4500 $\mathrm{mg} / \mathrm{L}$ glucose without sodium pyruvate, fetal bovine serum (FBS), and $1 \mathrm{X} 0.25 \%$ EDTA-trypsin were obtained from Thermo Scientific HyClone (Logan, UT, USA). The TRI reagent was purchased from Molecular Research Center, Inc. (Cincinnati, OH, USA). The RNase inhibitor, 100-bp DNA ladder, deoxyribonuclease I, and primers were all purchased from Bio Basic, Inc. (Ontario, Canada). The M-MuLV reverse transcriptase was purchased from Finnzymes, Inc. (Espoo, Finland). Amphotericin B (Fungizone) and penicillin-streptomycin solutions came from Biochrom AG (Berlin, Germany). All other basic reagents were of analytical grade.

\section{Preparation of HepG2 cells and biological analysis}

The HepG2 cell line was kindly donated by Associate Professor Dr. Parvapan Bhattarakosol, Faculty of Medicine, Chulalongkorn University, Bangkok, Thailand. HepG2 cells were grown in DMEM supplemented with $4 \mathrm{mM}$ glutamine, $4.5 \mathrm{~g} / \mathrm{L}$ glucose, $10 \%$ heat-inactivated FBS, 0.1\% amphotericin B (Fungizone), and 1\% penicillin-streptomycin, and were maintained at $37^{\circ} \mathrm{C}$ in a humidified atmosphere in $5 \% \mathrm{CO}_{2}$. The culture medium was changed twice a week, and the cells were subcultured once a week. The cells were seeded at a density of $1 \times 10^{6}$ cells/well on 6-well plates with a final volume of $5 \mathrm{~mL} /$ well for the RT-PCR assay and at $1 \times 10^{4}$ cells/well on 96-well plates with a final volume of $0.2 \mathrm{~mL} /$ well for the cell viability tests using the MTT and oxidative stress (DCFH-DA) assays, respectively.

\section{Preparation of $M$. oleifera extract}

The M. oleifera leaves were collected from an herb garden in Bangkok. The voucher specimen was botanically identified and designated with herbarium number 013521 (BCU) by 
the Botany Department, Faculty of Sciences, Chulalongkorn University, Bangkok, Thailand. The M. oleifera extract (MOE) was prepared from dried M. oleifera leaves. In brief, $10 \mathrm{~g}$ leaves were milled and extracted in $1000 \mathrm{~mL} 80 \%$ methanol in water. This mixture was shaken in an ultrasonic bath for $60 \mathrm{~min}$ at $40^{\circ} \mathrm{C}$, cooled, and stored in the dark at $4^{\circ} \mathrm{C}$ for 2 days, after which the sediment was removed by centrifugation at $3000 \mathrm{rpm}$ for $15 \mathrm{~min}$. The extract was concentrated using a vacuum rotary evaporator at $50^{\circ} \mathrm{C}$ and then freeze-dried giving a yield of $\sim 2 \mathrm{~g}$ dried extract. This dried extract was kept in a deep freezer at $-80^{\circ} \mathrm{C}$ until use.

\section{Determinations of antioxidants in MOE}

To investigate antioxidant levels in MOE, an oxygen radical absorbance capacity (ORAC) assay, an FCP assay, and a total flavonoids assay were used for determination of antioxidant properties.

\section{ORAC assay}

This assay was performed based on the procedure described by Davalos et al. (2004) with some modifications. It was used to measure the oxidative degradation of the fluorescent molecules after being mixed with the free radical generator, 2,2'-azobis (2-amidinopropane) dihydrochloride (AAPH). Antioxidants can protect fluorescent molecules from oxidative degradation. Briefly, $153 \mathrm{mM}$ AAPH (in phosphate buffer, $\mathrm{pH}$ 7.4) was freshly prepared. A $40-\mu \mathrm{M}$ fluorescein stock solution was prepared in phosphate buffer and stored at $4^{\circ} \mathrm{C}$. Immediately prior to use, the fluorescein stock solution was diluted 1:1000 with buffer. In addition, blank wells of a 96-well plate received $25 \mu \mathrm{L}$ buffer while standards received $25 \mu \mathrm{L}$ Trolox solutions $(10,20,30,40,60$, and $80 \mathrm{mM})$ and samples received $25 \mu \mathrm{L}$ appropriate diluted samples. Next, $150 \mu \mathrm{L}$ working fluorescein solution was added, and the solutions were mixed for $5 \mathrm{~s}$. The plate was equilibrated by incubating for a minimum of $10 \mathrm{~min}$ at $37^{\circ} \mathrm{C}$ in the Wallac 1420 VICTOR2 Multilabel Counter (Perkin Elmer Life and Analytical Sciences, Finland). Twentyfive microliters AAPH solution was then added to initiate the reaction, followed by shaking for $10 \mathrm{~s}$. Then, the fluorescence was kinetically monitored, and data ware recorded every minute using $485 \mathrm{~nm}$ for excitation and $535 \mathrm{~nm}$ for emission. The plate reader 1420 VICTOR2 was controlled with the Wallac 1420 software, version 3.00. The fluorescence of each well was measured every minute for $35 \mathrm{~min}$. ORAC values were calculated using the area under the curve (AUC). The AUC and the net AUC of the standards and samples were determined using the Wallac 1420 software with the following equations:

$$
\begin{array}{cc}
\text { Net AUC standard }=\text { AUC standard }- \text { AUC blank } & \text { Equation 1 } \\
\text { Net AUC sample }=\text { AUC sample }- \text { AUC blank } & \text { Equation 2 }
\end{array}
$$

The loss in fluorescence can be assessed by measuring the AUC of the kinetic plot at each concentration. The greater the extent of florescent decay, the smaller the expected AUC value. When net AUC values were calculated from these kinetic curves and plotted against Trolox concentration, a linear relationship was observed. The results are reported as Trolox equivalents (TE) $\mathrm{mM} / \mathrm{kg}$ dry mass. The total antioxidant level in MOE was determined in triplicate. 


\section{FCP assay}

A modified FCP assay (Singleton et al., 1999) was used to determine polyphenolic contents. Briefly, $500 \mu \mathrm{L}$ sample or standard was mixed with $500 \mu \mathrm{L} 10 \%$ FCP reagent, allowed to stand for $20 \mathrm{~min}$, mixed with $350 \mu \mathrm{L} 10 \mathrm{mM} \mathrm{Na}_{2} \mathrm{CO}_{3}$, and allowed to stand for 20 min. During this period, the solution turned blue in color and then absorbance was read at 750 $\mathrm{nm}$ using gallic acid as the standard with various concentrations: $1.562,3.125,6.25,12.5,25$, and $50 \mathrm{mg} / \mathrm{L}$. The results are reported as gallic acid equivalents (GE) $\mathrm{mM} / \mathrm{kg}$ dry mass. The total polyphenolic content in MOE was determined in triplicate.

\section{Total flavonoids assay}

Total flavonoid contents in the herbal extract were determined by colorimetric reaction (Zou et al., 2004) with some modifications. Each $0.5 \mathrm{~mL}$ aliquot diluted sample or standard (Quercetin) was added to $0.15 \mathrm{~mL} 5 \% \mathrm{NaNO}_{2}$ solution. After $6 \mathrm{~min}, 0.15 \mathrm{~mL} 10 \%$ freshly prepared $\mathrm{AlCl}_{3}$ solution was added and allowed to stand for $6 \mathrm{~min}$, and then $0.5 \mathrm{~mL} 1.0 \mathrm{M} \mathrm{NaOH}$ was added. The final volume was adjusted to $2.5 \mathrm{~mL}$ with distilled water, thoroughly mixed, and allowed to stand for another $15 \mathrm{~min}$. Absorbance was determined at $510 \mathrm{~nm}$ against the reagent blank. Total flavonoid content is reported as Quercetin equivalents (QE) $\mathrm{mM} / \mathrm{kg}$ dried mass. The total flavonoid content in MOE was determined in triplicate.

\section{Inhibition of AGE formation assay}

The formation of AGE was assessed using the fluorescence method (Matsuura et al., 2002 ) with some modifications. Briefly, $20 \mu \mathrm{L}$ various concentrations $\mathrm{MOE}$, amino guanidine (inhibitor), or phosphate buffer was added to the freshly prepared reaction mixture containing $400 \mu \mathrm{L} 1 \mathrm{mg} / \mathrm{mL}$ bovine serum albumin (BSA) and $80 \mu \mathrm{L} 1.0 \mathrm{M}$ glucose in phosphate buffer, $\mathrm{pH}$ 7.4. The reaction mixture was incubated at $60^{\circ} \mathrm{C}$ for $72 \mathrm{~h}$ (except for the control blank and test blank, which were kept at $4^{\circ} \mathrm{C}$ ), and was stopped by adding $25 \mu \mathrm{L} 100 \%$ trichloroacetic acid (TCA) $(\mathrm{w} / \mathrm{v})$. The TCA-added mixture was kept at $4^{\circ} \mathrm{C}$ for $10 \mathrm{~min}$ before centrifugation at $10,000 \mathrm{~g}$. The precipitant was dissolved with $1.0 \mathrm{~mL}$ alkaline phosphate buffer saline, $\mathrm{pH} 10$, and the amount of glycated BSA was immediately measured based on fluorescence intensity with a spectrofluorometer (Perkin Elmer Enspire 2300 Multilabel Reader). The excitation and emission wavelengths used were $370 \mathrm{~nm}$ and $440 \mathrm{~nm}$, respectively. The AGE content in MOE was determined in triplicate.

\section{MTT assay or cell viability of HepG2 cells}

HepG2 cell viability was assessed using the MTT assay as previously described by Twentyman and Luscombe (1987). Briefly, following the cell treatments, HepG2 cells in each well of the 96-well plate were subjected to MTT reagent by mixing with $20 \mu \mathrm{L}$ MTT solution [5 $\mathrm{g} / \mathrm{L}$ in phosphate-buffered saline (PBS), $\mathrm{pH} 7.4]$, and incubated at $37^{\circ} \mathrm{C}$ in $5 \% \mathrm{CO}_{2}$ for $4 \mathrm{~h}$. After the medium was removed, $150 \mu \mathrm{L} 50 \%$ ethanol in dimethyl sulfoxide was added to each well to dissolve the Formosan product, and the absorbance was measured at $550 \mathrm{~nm}$. Since the reduction of MTT occurred in active cells, the level of activity reflected the proportion 
of viable cells. The percentage of cellular activity was calculated according to the following formula: Cellular activity $(\%)=[($ absorbance of treatment group - blank/absorbance of control group - blank)] x 100. All samples were analyzed in triplicate.

\section{DCFH-DA assay for oxidative stress}

The DCFH-DA assay was used for measuring intracellular oxidative stress of HepG2 cells (Wang and Joseph, 1999). Briefly, following the cell treatments, HepG2 cells were centrifuged for $10 \mathrm{~min}$ at $2500 \mathrm{rpm}$ and then washed three times with PBS, pH 7.4. The cells were mixed with $100 \mu \mathrm{L} 100 \mathrm{mM}$ DCFH-DA in PBS, and incubated for $90 \mathrm{~min}$ at $37^{\circ} \mathrm{C}$ in a humidified 5\% $\mathrm{CO}_{2}$ atmosphere. The non-ionic, non-polar DCFH-DA crossed cell membranes were hydrolyzed by intracellular esterases to non-fluorescent dichlorofluorescin (DCFH). In the presence of reactive oxygen species (ROS) inside the cells, DCFH was oxidized to the highly fluorescent, dichlorofluorescein (DCF). The cells were centrifuged for $10 \mathrm{~min}$ at $2500 \mathrm{rpm}$ and then washed three times with PBS, $\mathrm{pH}$ 7.4. The fluorescent measurement was monitored using the Perkin Elmer Enspire 2300 Multilabel Reader at $485 \mathrm{~nm}$ and $535 \mathrm{~nm}$ for excitation and emission, respectively. Therefore, the intracellular DCF fluorescence could be used as an index to quantify the overall level of oxidative stress in the cells. The percent cellular oxidative stress was calculated according to the following formula: cellular oxidative stress $(\%)=$ [(fluorescence of treatment group - blank/fluorescence of control group - blank)] x 100. All samples were analyzed in triplicate.

\section{Detection of lipid metabolism gene expression using RT-PCR}

The expression of lipid metabolism genes, including the LDLR, HMG-CoAR, PPAR $(\alpha 1, \alpha 2, \gamma)$, and LXR $\alpha$ genes, in HepG2 cells was analyzed using the RT-PCR method according to previous reports (Powell and Kroon, 1994; Kaul et al., 2005) with slight modifications. Briefly, 1 x $10^{6}$ HepG2 cells suspended in DMEM on 6-well plates were mixed with MOE (0 to $600 \mathrm{mg} / \mathrm{L}$ with $0=$ control). After incubation for $29 \mathrm{~h}$ at $37^{\circ} \mathrm{C}$ in a humidified $5 \% \mathrm{CO}_{2}$ atmosphere, total RNA was isolated from HepG2 cells using the TRI reagent following the manufacturer protocol. Purity and quantity of total RNA were determined using agarose gel electrophoresis and a spectrophotometer. cDNA synthesis was performed using $2 \mathrm{mg}$ total RNA, random primers, and M-MuLV-reverse transcriptase at $42^{\circ} \mathrm{C}$ for $1 \mathrm{~h}$. Subsequently, PCR was carried out using specific primer pairs in order to generate PCR products, which were the 258-bp LDLR primers (sense 5'-CAATGTCTCACCAAGCTCTG-3'and antisense 5'-TCTGTCTCGAGGGGTAGCTG-3'), the 247-bp HMG-CoAR primers (sense 5'-CTTGTG TGTCCTTGGTATTAGAGCTT-3' and antisense 5'-TTATCATCTTGACCCTCTGAGTTA CAG-3'), the 728-bp PPAR $\alpha 1$ and the 525-bp PPAR $\alpha 2$ primers (sense 5'-AGTCTC CCAGTGGAGCATTGAACA-3' and antisense 5'-ATACGCTACCAGCATCCCGTCTTT-3'), the 434-bp PPAR $\gamma$ primers (sense 5'-AGCCTCATGAAGAGCCTTCCAACT-3' and antisense 5'-TGTCTTTCCTGTCAAGATCGCCCT-3'), the 818-bp LXR $\alpha$ primers (sense 5'-AACCCACAGAGATCCGTCCACAAA-3' and antisense 5'-ATTCATGGCCCTGGAGAA CTCGAA-3'), and the 656-bp $\beta$-actin primers (sense 5'-ACGGGTCACCCACACTGTGC-3' and antisense 5'-CTAGAAGCATTTGCGGTGGACGATG-3'). RT-PCR products along with a DNA ladder were electrophoresed on an agarose gel and visualized by ethidium bromide 
staining using a gel documentation system. For data analysis, the GeneTools software 3.08 (SynGene, Cambridge, UK) was utilized. The expression of genes was normalized to that of $\beta$-actin, and data for treatment with each $\mathrm{MOE}$ concentration are reported as fold-change in normalized mRNA expression relative to that of the no MOE treatment (control).

\section{Statistical analysis}

All data are reported as means $\pm \mathrm{SE}$ of at least three independent experiments. Statistically significant differences between control and treated groups were evaluated by one-way analysis of variance (ANOVA) in SPSS version 11.0 for Windows, followed by least significant differences statistical tests. The $\mathrm{P}$-value was two-tailed, and $\mathrm{P}<0.05$ was considered to be statistically significant when comparing the data sets.

\section{RESULTS}

\section{Determinations of total antioxidants and inhibitory effect of MOE on AGE formation}

We found that the lyophilized form of MOE in $80 \%$ ethanol possessed total antioxidant, polyphenolic, and flavonoid contents of $9307 \pm 364 \mathrm{TE} \mathrm{mM} / \mathrm{kg}$ dry mass, $218 \pm 1 \mathrm{GE} \mathrm{mM} / \mathrm{kg}$ dry mass, and $286 \pm 12 \mathrm{QE} \mathrm{mM/kg}$ dry mass using the ORAC assay, the FCP assay, and the total flavonoids assay, respectively (Table 1). At $2.5-10.0 \mathrm{mg} / \mathrm{mL}$ concentrations, MOE could inhibit 10-45\% AGE formation in a dose-dependent manner $(\mathrm{P}<0.05)$. In contrast, $33.0 \mathrm{mM}$ or $4.492 \mathrm{mg} / \mathrm{mL}$ amino guanidine, an AGE inhibitor, inhibited AGE by $50 \pm 0.5 \%$ (Table 2).

\begin{tabular}{|c|c|c|c|}
\hline Herb extract & $\begin{array}{c}\text { Total antioxidant } \\
\text { (TE } \mathrm{mM} / \mathrm{kg} \text { dry mass) } \\
(\mathrm{Means} \pm \mathrm{SE})\end{array}$ & $\begin{array}{l}\text { Total polyphenolics } \\
\text { (GE mM/kg dry mass) } \\
(\text { Means } \pm \mathrm{SE})\end{array}$ & $\begin{array}{c}\text { Total flavonoids } \\
(\mathrm{QE} \mathrm{mM} / \mathrm{kg} \text { dry mass }) \\
(\text { Means } \pm \mathrm{SE})\end{array}$ \\
\hline MOE & $9307 \pm 364$ & $218 \pm 1$ & $286 \pm 12$ \\
\hline
\end{tabular}

Values derived from means with their standard error (SE). All experiments were performed at least in 2 triplicates. $\mathrm{TE}=$ trolox equivalent, $\mathrm{GE}=$ gallic acid equivalent, $\mathrm{QE}=$ quercetin equivalent.

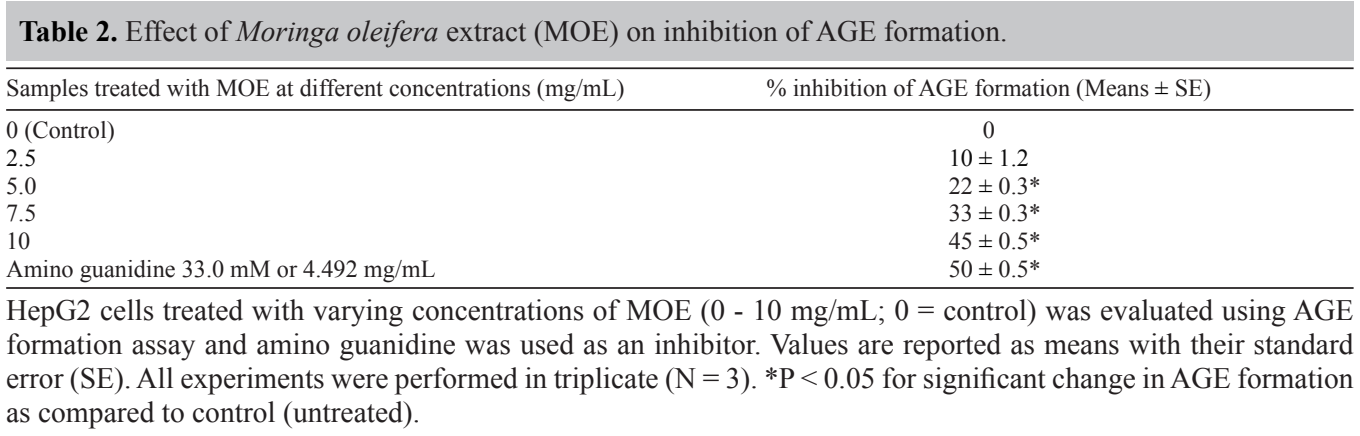




\section{Effect of MOE on cell viability and oxidative stress in HepG2 cells}

According to the HepG2 cells viability test, MOE at the $2000-3000 \mathrm{mg} / \mathrm{L}$ concentration range significantly reduced the numbers of living cells $(\mathrm{P}<0.05)$ using the MTT assay (Figure 1A). Oxidative stress induced ROS production, as determined by the DCFH-DA assay, and HepG2 cells treated with $>100 \mathrm{mg} / \mathrm{L}$ MOE significantly reduced oxidative stress in a dose-dependent manner $(\mathrm{P}<0.05)$ upon incubation for $29 \mathrm{~h}$ (Figure 1B).
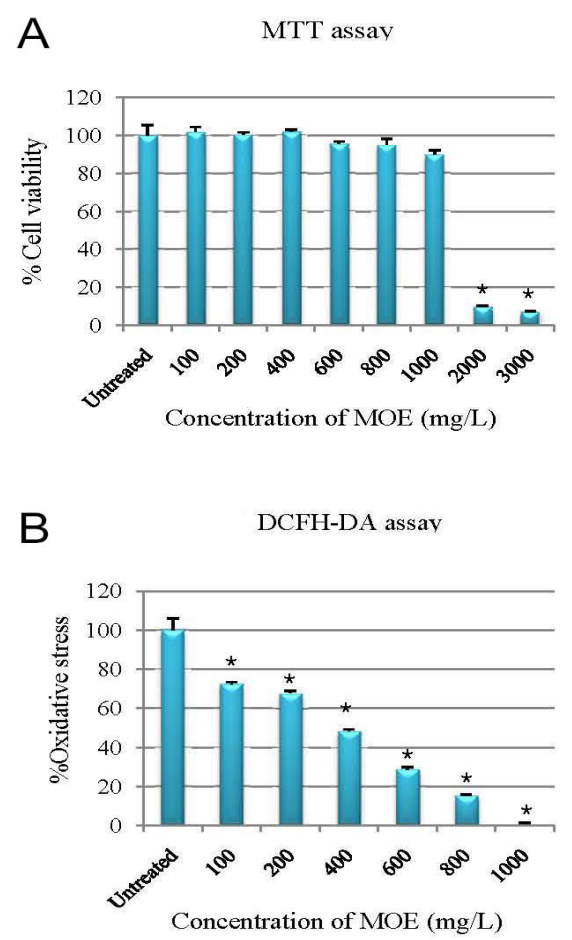

Figure1. Moringa oleifera extract (MOE) affected on cell viability and oxidative stress of HepG2 cells. HepG2 cells were incubated with different concentrations of $\mathrm{MOE}(0-3000 \mathrm{mg} / \mathrm{L})$ at the end of experimental periods of 29 h. A. The cell viability of living HepG2 cells was assessed using the MTT assay; B. The oxidative stress in HepG2 cells was evaluated using the DCFH-DA assay. Values are reported as means with their standard error of the mean (SEM) depicted by vertical bars. All experiments were performed in triplicate $(\mathrm{N}=3)$. $* \mathrm{P}<0.05$ for significant change as compared to control (no treatment).

\section{Effect of MOE on the expression of lipid metabolism-related genes in HepG2 cells}

With regard to the mRNA expression of lipid metabolism genes (Figure 2 and Table 3), $600 \mathrm{mg} / \mathrm{L} \mathrm{MOE}$ significantly reduced the expression of the HMG-CoAR, PPAR $\alpha 1$, and PPAR $\gamma$ genes in HepG2 cells $(\mathrm{P}<0.05)$. No difference in mRNA expression in response to various concentrations of MOE was observed for the LDLR and LXR $\alpha$ genes. The expression of PPAR $\alpha 2$ mRNA was detected simultaneously when using the PCR primer pair for PPAR $\alpha 1 \mathrm{mRNA}$, which was not of interest in the present study since it is known to be an inactive isoform. 
A.

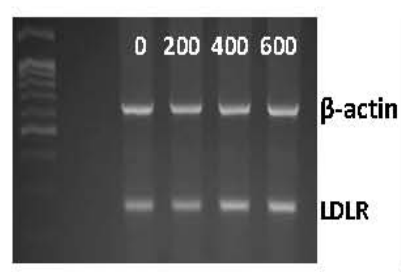

B.

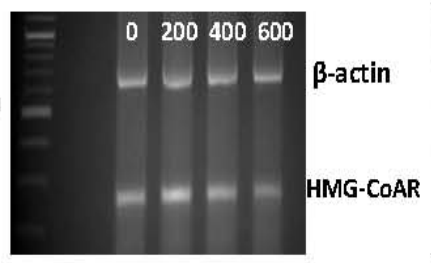

C.

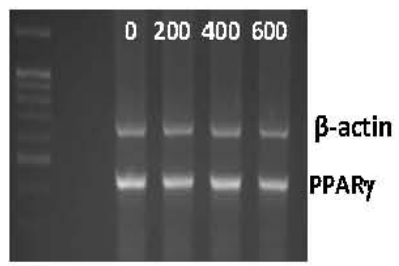

D.

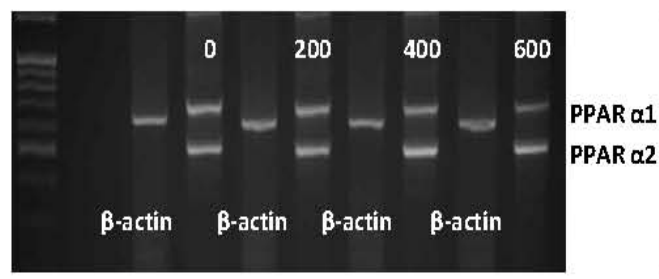

E.

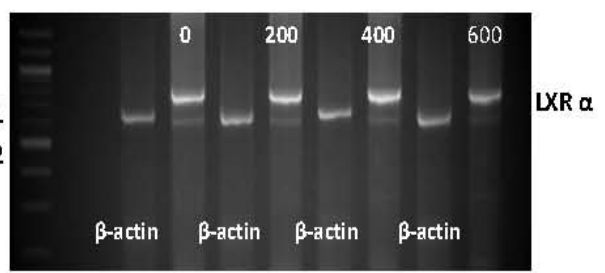

Figure2. Effect of Moringa oleifera extract (MOE) on mRNA expression of certain lipid metabolism genes of HepG2 cells using the RT-PCR approach. Representative agarose gel photographs showed RT-PCR products corresponding to expect sizes of the lipid metabolism genes studied, i.e., A.LDLR, B. HMG-CoAR, C. PPAR $\gamma$, D. PPAR $\alpha 1$, PPAR $\alpha 2$, and E. LXR $\alpha$. The mRNA expression of $\beta$-actin gene was used for normalization. HepG2 cells were treated with MOE ( 0 to $600 \mathrm{mg} / \mathrm{L} ; 0=$ control). LDLR $=$ low-density lipoprotein receptor; HMG-CoAR = 3-hydroxy-3-methylglutaryl-CoA reductase; PPAR = peroxisome proliferator-activated receptors; LXR $\alpha=$ liver $\mathrm{X}$ receptor $\alpha$.

Table 3. Effect of Moringa oleifera extract (MOE) on lipid metabolism gene expression of HepG2 cells.

\begin{tabular}{llcccc}
\hline MOE mg/L & $\begin{array}{c}\text { HMG-CoAR } \\
(\text { Means } \pm \text { SE) }\end{array}$ & $\begin{array}{c}\text { LXR } \alpha \\
(\text { Means } \pm \text { SE) }\end{array}$ & $\begin{array}{c}\text { LDLR } \\
(\text { Means } \pm \text { SE) }\end{array}$ & $\begin{array}{c}\text { PPAR } \alpha 1 \\
\text { (Means } \pm \text { SE) }\end{array}$ & $\begin{array}{c}\text { PPAR } \gamma \\
(\text { Means } \pm \text { SE) }\end{array}$ \\
\hline 0 & $0.999 \pm 0.028$ & $1.000 \pm 0.042$ & $1.000 \pm 0.032$ & $1.000 \pm 0.081$ & $1.000 \pm 0.058$ \\
200 & $1.027 \pm 0.015$ & $1.059 \pm 0.072$ & $0.906 \pm 0.044$ & $0.895 \pm 0.064$ & $0.948 \pm 0.095$ \\
400 & $0.974 \pm 0.040$ & $1.057 \pm 0.059$ & $1.032 \pm 0.031$ & $0.833 \pm 0.056$ & $0.931 \pm 0.051$ \\
600 & $0.781 \pm 0.066^{*}$ & $1.031 \pm 0.076$ & $1.061 \pm 0.004$ & $0.550 \pm 0.061^{*}$ & $0.568 \pm 0.010^{*}$ \\
\hline
\end{tabular}

The mRNA expression of lipid metabolism genes; PPAR $\gamma$, PPAR $\alpha 1$, LDLR and HMGCoAR of HepG2 cells treated with varying concentrations of $\mathrm{MOE}(0-600 \mathrm{mg} / \mathrm{L} ; 0=$ control $)$ were evaluated using RT-PCR. The mRNA expression of the genes studied was normalized to that of the $\beta$-actin gene. Values derived from normalized band intensities are reported means with their standard error (SE) from Figure 2. All experiments were performed in triplicate $(\mathrm{N}=3) . * \mathrm{P}$ $<0.05$ for significant change in normalized gene expression as compared to control.

\section{DISCUSSION}

We found that the lyophilized form of M. oleifera extract in $80 \%$ ethanol possessed total antioxidant, polyphenolic, and flavonoid contents of $9307 \pm 364 \mathrm{TE} \mathrm{mM} / \mathrm{kg}$ dry mass, 218 $\pm 1 \mathrm{GE} \mathrm{mM} / \mathrm{kg}$ dry mass, and $286 \pm 12 \mathrm{QE} \mathrm{mM} / \mathrm{kg}$ dry mass using the ORAC assay, the FCP assay, and the total flavonoids assay, respectively. The high performance liquid chromatography analysis of MOE indicated the presence of the bioactive compounds kaempferol, quercetin, ru- 
tin, and gallic, chlorogenic, ellagic, and ferulic acids (Verma et al., 2009). Therefore, the therapeutic effects of $M$. oleifera may be due to the combination of various bioactive compounds. $M$. oleifera leaves could prevent excessive oxidation of macromolecules such as DNA, proteins, and lipids (Chumark et al., 2008; Uma et al., 2010; Moyo et al., 2012). The major chemicals of oxidative stress are ROS and free radicals. All cells can fight against this stress through the actions of antioxidant enzymes such as catalase, superoxide dismutase, glutathione peroxidase, and reducing molecules such as glutathione. Exogenous antioxidants, such as vitamins A, C, and E, also provide protection from oxidative stress (Limon-Pacheco and Gonsebatt, 2009). MOE was found to inhibit AGE formation in a dose-dependent manner $(\mathrm{P}<0.05)$. With respect to achieving good glycemic control, a diet combination that reduces AGE consumption should be the target for management of diabetic patients. High blood glucose can auto-oxidize to form hydrogen peroxide and ketoaldehyde compounds in the presence of transition metal ions, which then accelerates the formation of AGE (Wolff et al., 1991). AGE could modify LDL cholesterol levels, which becomes easy to oxidize, is deposited in vessel walls, and finally causes plaque formation. These particles are easy to oxidize and are potent initiators of atherogenesis and its associated vascular damage. M. oleifera leaves were found to possess hypolipidemic and antiatherosclerotic activities, and have therapeutic potential for the prevention of cardiovascular diseases (Chumark et al., 2008). The inhibitory mechanism of flavonoids against glycation may be due to their antioxidant properties (Wu and Yen, 2005). A reduction of more than 50\% AGE intake could reduce approximately $30 \%$ of the circulating AGE within 1 month (Peppa et al., 2003). MOE is efficient enough to inhibit AGE formation. However, the inhibitory effect of MOE was less than half of that of amino guanidine (Table 2). MOE is a natural source that has been long consumed as food or herbs. Therefore, M. oleifera provides a safe, cheap, and easy to handle source of alternative medicine. Moreover, the bioactive phenolic glycoside, 4-[(2'-O-acetyl- $\alpha$-L-rhamnosyloxy) benzyl] isothiocyanate, of M. oleifera was found to decrease inducible nitric oxide synthase expression and inhibit cyclooxygenase-2, which shows its potential for anti-inflammatory and cancer chemoprevention activities (Park et al., 2011).

According to the HepG2 cell viability test, $2000-3000 \mathrm{mg} / \mathrm{L}$ MOE significantly reduced the number of living cells. In oxidative stress-induced ROS production detected with the DCFH-DA assay, we found that $100-1000 \mathrm{mg} / \mathrm{L}$ MOE could reduce oxidative stress in HepG2 cells. Therefore, the toxic effect of MOE at high doses may be due to its inhibitory or stimulatory actions via kinase signaling pathways, which are likely to affect cellular functions by altering the phosphorylation state of target molecules and by modulating gene expression (Williams et al., 2004). These findings suggested that MOE at high concentrations might not be appropriate for health-promoting purposes. Other studies have indicated that lower concentrations of flavonoids (nanomolar level to low micromolar levels) could lead to antioxidant response element-mediated gene expression, including that of phase II detoxifying enzymes. In contrast, higher concentrations of flavonoids may sustain the activation of mitogen-activated protein kinases or stress-activated protein kinases, which could induce apoptosis (Chen et al., 2000; Kong et al., 2000) and direct activation of the caspase cascade in the mitochondrial pathway by inhibiting survival signaling (Granado-Serrano et al., 2006). Several studies have described the adverse actions of flavonoids at the cellular level. For example, due to the toxic effects of flavonoids at high concentrations, DNA strand breaks are induced when using flavonoids such as quercetin and kaempferol (Beatty et al., 2000; Niering et al., 2005).

Using the RT-PCR method for analyzing the effect of MOE on lipid metabolism gene 
expression, MOE was shown to significantly decrease the expression of the HMG-CoAR, PPAR $\alpha 1$, and PPAR $\gamma$ genes of HepG2 cells. MOE inhibited lipid synthesis by downregulating HMG-CoAR, PPAR $\alpha 1$, and PPAR $\gamma$ gene expression, which reduced lipid metabolism. Furthermore, MOE also reduced glucose metabolism by downregulating PPAR $\gamma$ gene expression inside the cells. PPAR- $\alpha$ and PPAR- $\gamma$ are crucial for lipid and glucose metabolism, respectively. The discovery of PPAR- $\alpha$ and PPAR- $\gamma$ agonists, such as fibrates and thiazolidinediones, respectively, showed that they might be involved in reducing the adverse effects of chronic disorders such as atherosclerosis and diabetes (Kota et al., 2005). The present study showed that these particular genes might regulate energy metabolism in the HepG2 cells. Other natural products have been used to examine lipid lowering effects, such as hesperidin, naringin (Jung et al., 2006), resveratrol (Do et al., 2008), and curcumin (Jang et al., 2008), which could also decrease hepatic HMG-CoAR. In contrast, red wine polyphenols (Pal et al., 2003) and anthocyanins in black sticky rice (Sangkitikomol et al., 2010) have been shown to increase hepatic LDLR. In addition, $\beta$-sitosterol in $M$. oleifera leaves has also been shown to decrease intestinal uptake of cholesterol (Lin et al., 2010). In conclusion, these results suggest that $M$. oleifera could decrease plasma cholesterol and lipid synthesis by suppression of HMG-CoAR, PPAR $\alpha 1$, and PPAR $\gamma$ gene expression, thereby maintaining lipid homeostasis.

\section{ACKNOWLEDGMENTS}

Research supported by the Rachadaphisaksomphot Endowment Fund Part of the Strengthen CU's Researcher Project and the Chulalongkorn University Centenary Academic Development Project. The authors gratefully acknowledge the generous gift of the HepG2 cells from Assoc. Prof. Dr. Parvapan Bhattarakosol.

\section{REFERENCES}

Bays H and Stein EA (2003). Pharmacotherapy for dyslipidaemia - current therapies and future agents. Expert Opin. Pharmacother. 4: 1901-1938.

Beatty ER, O'Reilly JD, England TG, McAnlis GT, et al. (2000). Effect of dietary quercetin on oxidative DNA damage in healthy human subjects. Br. J. Nutr. 84: 919-925.

Calkin AC and Tontonoz P (2010). Liver x receptor signaling pathways and atherosclerosis. Arterioscler. Thromb. Vasc. Biol. 30: 1513-1518.

Chen C, Yu R, Owuor ED and Kong AN (2000). Activation of antioxidant-response element (ARE), mitogen-activated protein kinases (MAPKs) and caspases by major green tea polyphenol components during cell survival and death. Arch. Pharm. Res. 23: 605-612.

Chumark P, Khunawat P, Sanvarinda Y, Phornchirasilp S, et al. (2008). The in vitro and ex vivo antioxidant properties, hypolipidaemic and antiatherosclerotic activities of water extract of Moringa oleifera Lam. leaves. J. Ethnopharmacol. 116: 439-446.

Davalos A, Gomez-Cordoves C and Bartolome B (2004). Extending applicability of the oxygen radical absorbance capacity (ORAC-fluorescein) assay. J. Agric. Food Chem. 52: 48-54.

Do GM, Kwon EY, Kim HJ, Jeon SM, et al. (2008). Long-term effects of resveratrol supplementation on suppression of atherogenic lesion formation and cholesterol synthesis in apo E-deficient mice. Biochem. Biophys. Res. Commun. 374: 55-59.

Fu MX, Requena JR, Jenkins AJ, Lyons TJ, et al. (1996). The advanced glycation end product, Nepsilon-(carboxymethyl) lysine, is a product of both lipid peroxidation and glycoxidation reactions. J. Biol. Chem. 271: 9982-9986.

Granado-Serrano AB, Martin MA, Bravo L, Goya L, et al. (2006). Quercetin induces apoptosis via caspase activation, regulation of Bcl-2, and inhibition of PI-3-kinase/Akt and ERK pathways in a human hepatoma cell line (HepG2). J. Nutr. 136: 2715-2721. 
Jang EM, Choi MS, Jung UJ, Kim MJ, et al. (2008). Beneficial effects of curcumin on hyperlipidemia and insulin resistance in high-fat-fed hamsters. Metabolism 57: 1576-1583.

Jung UJ, Lee MK, Park YB, Kang MA, et al. (2006). Effect of citrus flavonoids on lipid metabolism and glucose-regulating enzyme mRNA levels in type-2 diabetic mice. Int. J. Biochem. Cell Biol. 38: 1134-1145.

Kaul D, Shukla AR, Sikand K and Dhawan V (2005). Effect of herbal polyphenols on atherogenic transcriptome. Mol. Cell Biochem. 278: 177-184.

Kong AN, Yu R, Chen C, Mandlekar S, et al. (2000). Signal transduction events elicited by natural products: role of MAPK and caspase pathways in homeostatic response and induction of apoptosis. Arch. Pharm. Res. 23: 1-16.

Kota BP, Huang TH and Roufogalis BD (2005). An overview on biological mechanisms of PPARs. Pharmacol. Res. 51: 85-94.

Limon-Pacheco J and Gonsebatt ME (2009). The role of antioxidants and antioxidant-related enzymes in protective responses to environmentally induced oxidative stress. Mutat. Res. 674: 137-147.

Lin X, Racette SB, Lefevre M, Spearie CA, et al. (2010). The effects of phytosterols present in natural food matrices on cholesterol metabolism and LDL-cholesterol: a controlled feeding trial. Eur. J. Clin. Nutr. 64: 1481-1487.

Luevano-Contreras C, Garay-Sevilla ME and Chapman-Novakofski K (2013). Role of dietary advanced glycation end products in diabetes mellitus. JEBCAM 18: 50-66.

Matsuura N, Aradate T, Sasaki C and Kojima H (2002). Screening system for the Maillard reaction inhibitor from natural product extracts. J. Health Sci. 48: 520-526.

Moyo B, Oyedemi S, Masika PJ and Muchenje V (2012). Polyphenolic content and antioxidant properties of Moringa oleifera leaf extracts and enzymatic activity of liver from goats supplemented with Moringa oleifera leaves/sunflower seed cake. Meat. Sci. 91: 441-447.

Niering P, Michels G, Watjen W, Ohler S, et al. (2005). Protective and detrimental effects of kaempferol in rat H4IIE cells: implication of oxidative stress and apoptosis. Toxicol. Appl Pharmacol. 209: 114-122.

Pal S, Ho N, Santos C, Dubois P, et al. (2003). Red wine polyphenolics increase LDL receptor expression and activity and suppress the secretion of ApoB100 from human HepG2 cells. J. Nutr. 133: 700-706.

Park EJ, Cheenpracha S, Chang LC, Kondratyuk TP, et al. (2011). Inhibition of lipopolysaccharide-induced cyclooxygenase-2 and inducible nitric oxide synthase expression by 4-[(2'-O-acetyl-alpha-L-rhamnosyloxy)benzyl] isothiocyanate from Moringa oleifera. Nutr. Cancer 63: 971-982.

Peppa M, Uribarri J and Vlassara H (2003). Glucose, advanced glycation end products, and diabetes complications: What is new and what works. Clin. Diabetes 21: 186-187.

Powell EE and Kroon PA (1994). Low density lipoprotein receptor and 3-hydroxy-3-methylglutaryl coenzyme A reductase gene expression in human mononuclear leukocytes is regulated coordinately and parallels gene expression in human liver. J. Clin. Invest. 93: 2168-2174.

Sangkitikomol W, Tencomnao T and Rocejanasaroj A (2010). Effects of Thai black sticky rice extract on oxidative stress and lipid metabolism gene expression in HepG2 cells. Genet. Mol. Res. 9: 2086-2095.

Sato T, Iwaki M, Shimogaito N, Wu X, et al. (2006). TAGE (toxic AGEs) theory in diabetic complications. Curr. Mol. Med. 6: 351-358.

Singleton VL, Orthofer R and Lamuela-Raventós RM (1999). Analysis of total phenols and other oxidation substrates and antioxidants by means of folin-ciocalteu reagent. Meth. Enzymol. 299: 152-178.

Takeuchi M, Takino J and Yamagishi S (2010). Involvement of the toxic AGEs (TAGE)-RAGE system in the pathogenesis of diabetic vascular complications: a novel therapeutic strategy. Curr. Drug Targets 11: 1468-1482.

Twentyman PR and Luscombe M (1987). A study of some variables in a tetrazolium dye (MTT) based assay for cell growth and chemosensitivity. Br. J. Cancer 56: 279-285.

Uma N Jr, Fakurazi S and Hairuszah I (2010). Moringa oleifera enhances liver antioxidant status via elevation of antioxidant enzymes activity and counteracts paracetamol-induced hepatotoxicity. Malays. J. Nutr. 16: 293-307.

Uribarri J, Cai W, Sandu O, Peppa M, et al. (2005). Diet-derived advanced glycation end products are major contributors to the body's AGE pool and induce inflammation in healthy subjects. Ann. N.Y. Acad. Sci. 1043: 461-466.

Uribarri J, Woodruff S, Goodman S, Cai W, et al. (2010). Advanced glycation end products in foods and a practical guide to their reduction in the diet. J. Am. Diet. Assoc. 110: 911-916.

Verma AR, Vijayakumar M, Mathela CS and Rao CV (2009). In vitro and in vivo antioxidant properties of different fractions of Moringa oleifera leaves. Food Chem. Toxicol. 47: 2196-2201.

Wang H and Joseph JA (1999). Quantifying cellular oxidative stress by dichlorofluorescein assay using microplate reader. Free Radic. Biol. Med. 27: 612-616.

Williams RJ, Spencer JP and Rice-Evans C (2004). Flavonoids: antioxidants or signalling molecules? Free Radic. Biol. Med. 36: 838-849.

Willson TM, Lambert MH and Kliewer SA (2001). Peroxisome proliferator-activated receptor gamma and metabolic 
disease. Аnпu. Rev. Biochem. 70: 341-367.

Wolff SP, Jiang ZY and Hunt JV (1991). Protein glycation and oxidative stress in diabetes mellitus and ageing. Free Radic. Biol. Med. 10: 339-352.

$\mathrm{Wu} \mathrm{CH}$ and Yen GC (2005). Inhibitory effect of naturally occurring flavonoids on the formation of advanced glycation endproducts. J. Agric. Food Chem. 53: 3167-3173.

Zou Y, Lu Y and Wei D (2004). Antioxidant activity of a flavonoid-rich extract of Hypericum perforatum L. in vitro. J. Agric. Food Chem. 52: 5032-5039. 